\title{
A hybrid approach to forensic study of bridge scour
}

\section{Kornel Kerenyi}

Research Hydraulics Engineer, FHWA Turner-Fairbank Highway Research

Center, McLean, VA, USA (corresponding author: kornel.kerenyi@dot.gov)
Kevin Flora

Senior Bridge Engineer, Hydraulics Branch, Structure Maintenance and

Investigation, California Department of Transportation, Sacramento, CA, USA

The Feather River Bridge on Route 20 in Northern California, USA, was damaged by scour during a relatively modest flow event in March 2011. The scour created a hole around the foundation which was nearly 30 feet $(9.14 \mathrm{~m})$ deep and which permanently reduced the pile capacity at the main channel pier, requiring an emergency contract to repair the damaged structure. Following the event, several studies were made to help explain the causes of the scour event, including a geomorphological survey of the bank erosion history causing the high degree of misalignment of the flow, a laboratory flume study to examine the evolution of the scour hole and threedimensional computational fluid dynamics experiments for studying the decay and magnitude of the erosion forces for various scour depths. An additional goal of the modelling was to investigate why the scour ceased at 30 feet and to estimate the erosion forces in the scour hole at that depth.

\author{
Notation \\ $D_{50} \quad$ median sediment diameter: feet $(\mathrm{ft})(\mathrm{m})$ \\ g gravitational acceleration: $\mathrm{ft} / \mathrm{s}^{2}\left(\mathrm{~m} / \mathrm{s}^{2}\right)$ \\ $n \quad$ Manning's roughness coefficient (dimensionless) \\ $R_{\mathrm{h}} \quad$ hydraulic radius: $\mathrm{ft}(\mathrm{m})$ \\ $V \quad$ approach flow velocity \\ $y^{+} \quad$ dimensionless wall distance \\ $y_{\mathrm{s}} \quad$ pier-scour depth: $\mathrm{ft}(\mathrm{m})$ \\ $y_{\mathrm{s}, \max }$ maximum pier-scour depth: $\mathrm{ft}(\mathrm{m})$ \\ $\rho$ density of water: pounds $/ \mathrm{ft}^{3}\left(\mathrm{~kg} / \mathrm{m}^{3}\right)$ \\ $\tau_{*} \quad$ dimensionless shear stress \\ $\tau_{\mathrm{a}} \quad$ approach wall shear stress: pounds-force $/ \mathrm{ft}^{2}\left(\mathrm{lbf} / \mathrm{ft}^{2}\right)$ \\ $\left(\mathrm{N} / \mathrm{m}^{2}\right.$ or $\left.\mathrm{Pa}\right)$ \\ $\tau_{\mathrm{c}} \quad$ critical shear stress: $\mathrm{lbf} / \mathrm{ft}^{2}\left(\mathrm{~N} / \mathrm{m}^{2}\right.$ or $\left.\mathrm{Pa}\right)$ \\ $\tau_{\mathrm{w}} \quad$ local wall shear stress: $\mathrm{lbf} / \mathrm{ft}^{2}\left(\mathrm{~N} / \mathrm{m}^{2}\right.$ or $\left.\mathrm{Pa}\right)$
}

\section{Introduction}

\subsection{Background}

Bridge scour hazard has caused a significant number of bridge failures in the USA in the past decades. It was among the top issues in bridge design and maintenance (Lee et al., 2011). Significant research has been completed on pier scour. However, several needs remain, including a better definition of the effects of complex pier configurations on scour. In addition, much research has been conducted on homogeneous bed materials, whereas many field conditions are typified by multiple soil layers with varied properties. This forensic study was designed to develop a decay function of shear stress that occurs at the bottom of a scour hole as it is forming using a combination of physical experiments and computational fluid dynamics (CFD) simulations to understand and explain the scour damage of the Feather River Bridge on Route 20 in Northern California during a relatively modest flow event (between 5- and 10-year flow event) occurring in March 2011. Due to high flow velocities, a massive scour hole developed around pier 22 of the Feather River Bridge (Bridge Number
18-0009) on Route 20 in Sutter County, California. This scour left the structure vulnerable to failure during the next high-flow event and instigated an emergency structural retrofit of the pier. As part of the retrofit design, scour analysis was made to assess the stability of the proposed design. In the past, the Feather River Bridge had previously experienced scour at the main channel pier (pier 22) and was believed to be vulnerable at the piers along the main channel banks (piers 21 and 23) and considered scour critical since 2001. In addition, a 2010 study of the ongoing bank erosion along the east bank demonstrated that numerous piers in the overbank are also vulnerable to scour in the future. An in-depth discussion of the scour history and past scour evaluations have been previously documented in the Advanced Hydraulic, Scour and Geomorphic Study Report for this structure (Flora, 2010).

Moderately high releases from the upstream Oroville Reservoir in March 2011 produced flows that went out of bank in the channel and partially inundated the east overbank. The peak discharge occurred on 20 March 2011 and was estimated to be about $44500 \mathrm{feet}^{3} / \mathrm{s}\left(\mathrm{ft}^{3} / \mathrm{s}\right)\left(1260 \mathrm{~m}^{3} / \mathrm{s}\right)$ at a maximum water surface elevation of $56.4 \mathrm{ft}(17 \mathrm{~m})$, as shown in the hydrograph taken from a gauge located about $1800 \mathrm{ft}(549 \mathrm{~m})$ downstream of the Route 20 bridge (Figure 1). The scour caused by this event was of additional concern because the peak flow rate was much less than the estimated 100-year flood of $160800 \mathrm{ft}^{3} / \mathrm{s}\left(4757 \mathrm{~m}^{3} / \mathrm{s}\right)$.

A boat channel survey using a SonarMite echo sounder taken on 22 March 2011 revealed a substantial scour hole around pier 22. A follow-up survey on 24 March and a more extensive bathymetric survey extending from about $1500 \mathrm{ft}(460 \mathrm{~m})$ upstream of the Route 20 bridge to about $2700 \mathrm{ft}(823 \mathrm{~m})$ downstream of the bridge on 28 March 2011 confirmed the depth of the scour hole and that the channel thalweg had also moved eastwards, as shown in Figure 2. Based on these surveys, the minimum channel elevation had reached elevation $6 \mathrm{ft}(1.8 \mathrm{~m})$ at the upstream, span 21 side of pier 22. 


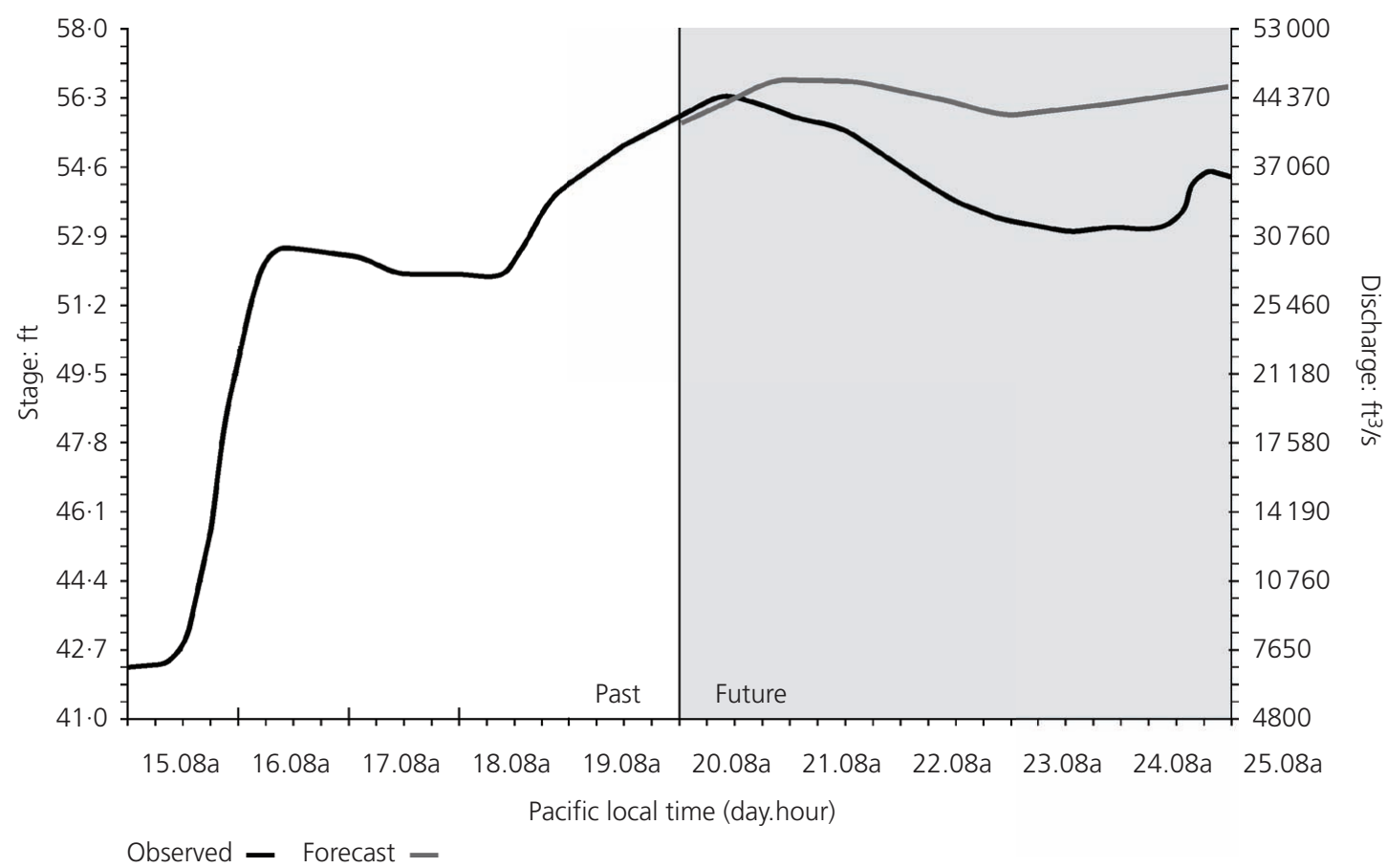

Figure 1. National Oceanic and Atmospheric Administration hydrograph. $1 \mathrm{ft}=0.305 \mathrm{~m} ; 1000 \mathrm{ft}^{3} / \mathrm{s}=28.3 \mathrm{~m}^{3} / \mathrm{s}$

On 30 March 2011, the California Department of Transportation contracted with Bay Marine Services to survey the channel with a multibeam sonar system. Using a Sonic 2024 echo sounder from R2Sonic, the scour hole under the bridge was clearly delineated (Figure 3) and the amount of scour under pier 22 was accurately mapped and quantified, as shown in Figures 4 and 5. It was determined that, while the maximum scour reached a depth of elevation $6 \mathrm{ft}(1.8 \mathrm{~m})$ at the upstream eastern portion of pier 22 exposing approximately $19 \mathrm{ft}(5.79 \mathrm{~m})$ of piles, less scour had occurred on the downstream western portion of the pier, exposing only $3-4 \mathrm{ft}(0.91-1.22 \mathrm{~m})$ of piles. This finding clarified why the

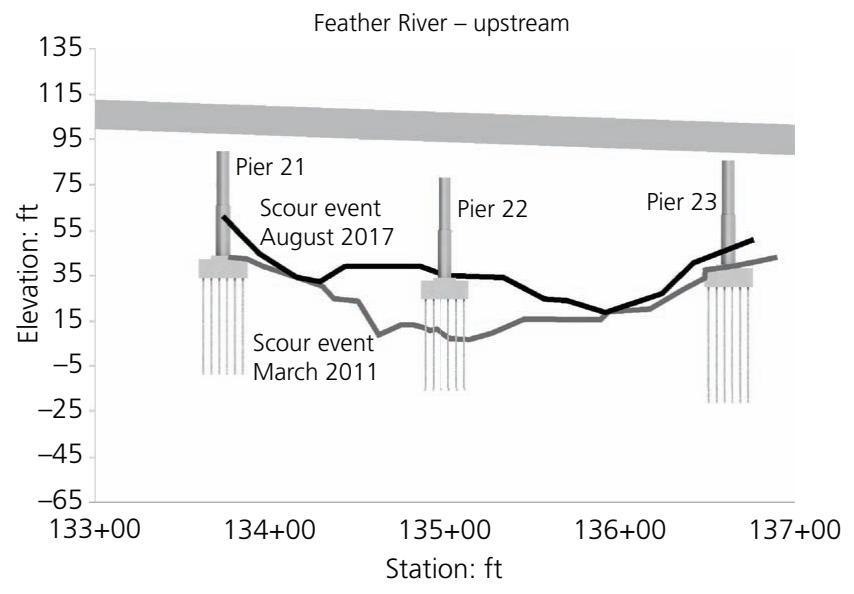

Figure 2. Cross-sectional comparison between 2007 and March 2011. $1 \mathrm{ft}=0.305 \mathrm{~m}$ bridge had not actually failed at this point but nevertheless confirmed the severity of the scour and the precarious status of the stability of the structure requiring corrective measures to be taken at this stage.

\subsection{Study objectives}

This study was designed to explore the scour potential of the complex pier configurations of both the original and retrofit designs, including consideration of the multilayer bed materials at

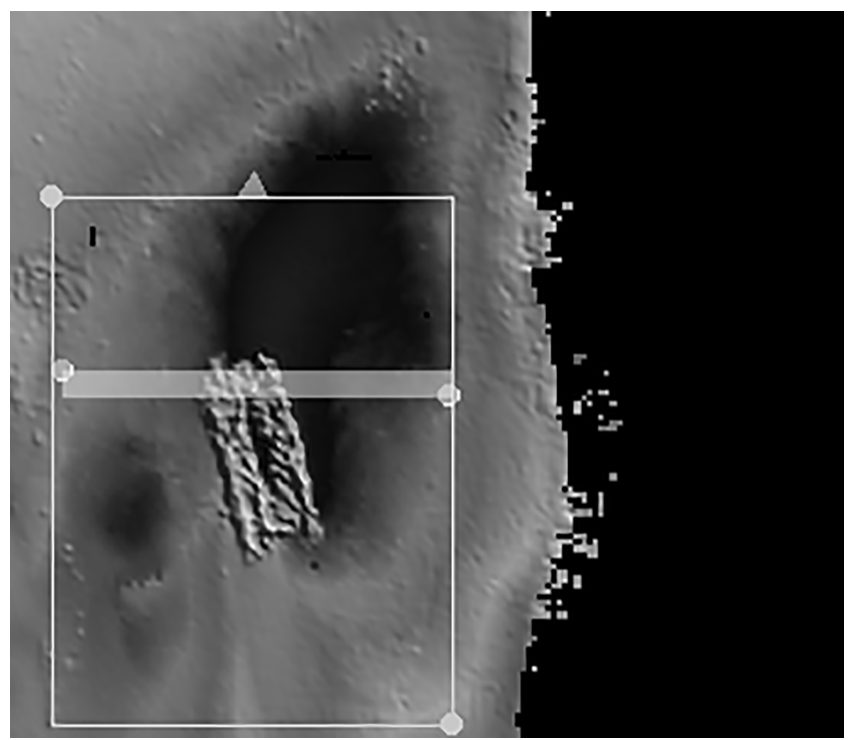

Figure 3. Multibeam delineation of the scour hole around pier 22 
Forensic Engineering

Volume 172 Issue FE1
A hybrid approach to forensic study of

bridge scour

Kerenyi and Flora

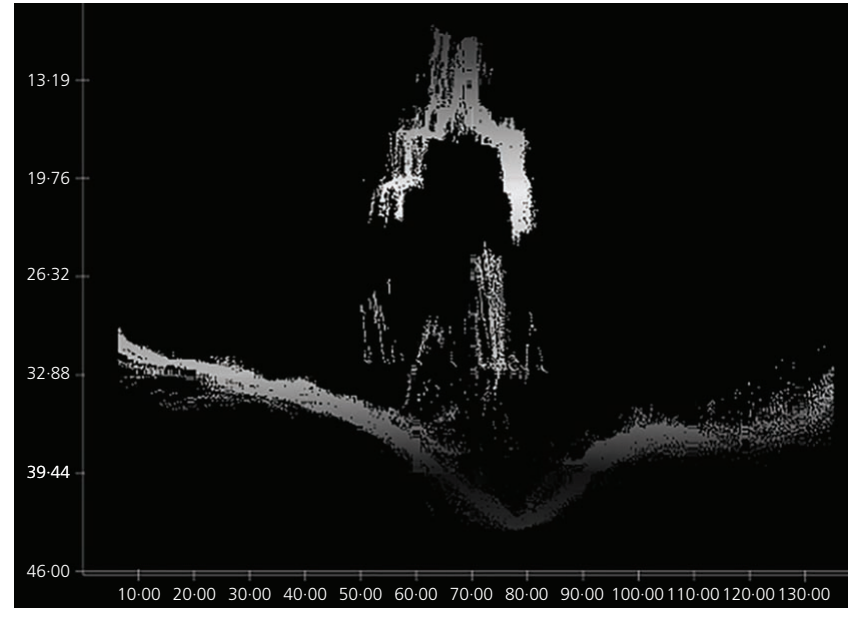

Figure 4. Upstream cross-section looking upstream

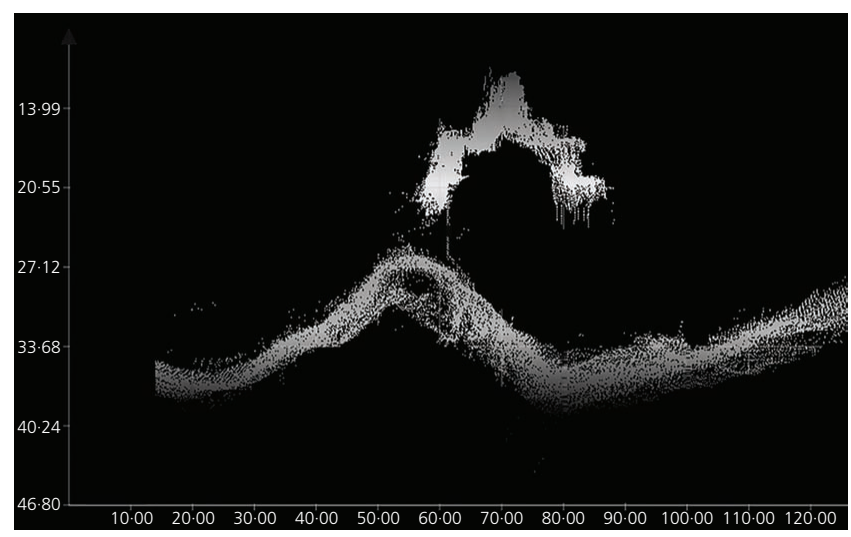

Figure 5. Downstream cross-section looking upstream

the site. A series of physical experiments and CFD simulations using 1:60 scaled pier models of the original and retrofit pier 22 was conducted in the Hydraulics Laboratory of the Federal Highway Administration (FHWA) facility in McLean, Virginia. CFD methods were applied to simulate these physical experiments as part of a hybrid approach to studying scour and the relation between shear stress and scour.

Pier 22 is an elliptical cylinder. The original foundation was a pile cap on top of 90 steel H-piles, as shown in Figure 6. Concern about the stability of the pier led to the design and installation of an emergency retrofit that was completed in December 2011 and is also shown in Figure 6. This design included an enlarged pile cap on top of the existing pile cap with ten $4 \mathrm{ft}$ dia. $(1 \cdot 22 \mathrm{~m}$ dia.) cast-in-steel shell (CISS) piles.

The study features a hybrid approach of physical experiments and CFD simulations to compensate for the weaknesses of each approach. In physical experimentation, it is challenging to measure wall shear stress directly on a dynamic riverbed. It is

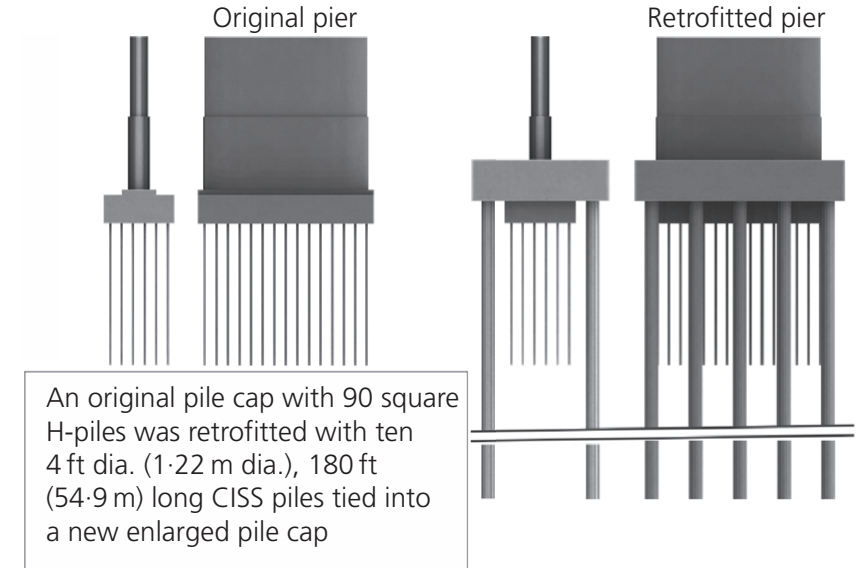

Figure 6. Sketches of the geometries of the original and retrofitted pier configurations. CISS, cast-in-steel shell

almost impossible to survey wall shear stress precisely in time or space because of the dynamic nature of the channel response to scour and the transport of material.

Pier-scour-estimation methods and laboratory pier-scour experiments generally assume homogeneous soil conditions. However, many bridge piers are located in heterogeneous conditions with multiple soil layers with varied scour resistance properties. This study attempts to formulate a decay function of wall shear stress with scour depth that allows a layer-by-layer evaluation of scour potential by matching the shear stress imposed by the flow at a given scour depth with the resistance of the soil at that depth. This can be useful in the design of new bridge piers by potentially identifying a buried soil layer that has the capacity to prevent further scour. It may also be useful in evaluating existing bridge scour situations, such as pier 22 of the Feather River Bridge, to assess the likelihood of further scour.

\section{The physical experiments}

\subsection{Overview}

The objective of the physical experiments for this study was to establish a series of scoured bathymetries around different pier configurations under different flow conditions. The experimental arrangements and devices are discussed. Also described is the scaling of the two flow conditions applicable to the Feather River Bridge site: (a) the March 2011 flood (MF) event and (b) the estimated 100-year discharge (Q100).

The physical experiments were conducted at the FHWA J. Sterling Jones Hydraulics Research Laboratory, shown in Figure 7. The laboratory's old tilting flume (outphased 2015) was used for the tests. The old flume was $6 \mathrm{ft}(1.82 \mathrm{~m})$ wide and $70 \mathrm{ft}$ $(21.3 \mathrm{~m})$ long with a sediment recess near the middle for local scour modelling. The flume had a total pumping capacity of $13 \cdot 4 \mathrm{ft}^{3} / \mathrm{s}(3791 / \mathrm{s})$ with a variable-frequency drive capable of 
A hybrid approach to forensic study of

bridge scour

Kerenyi and Flora

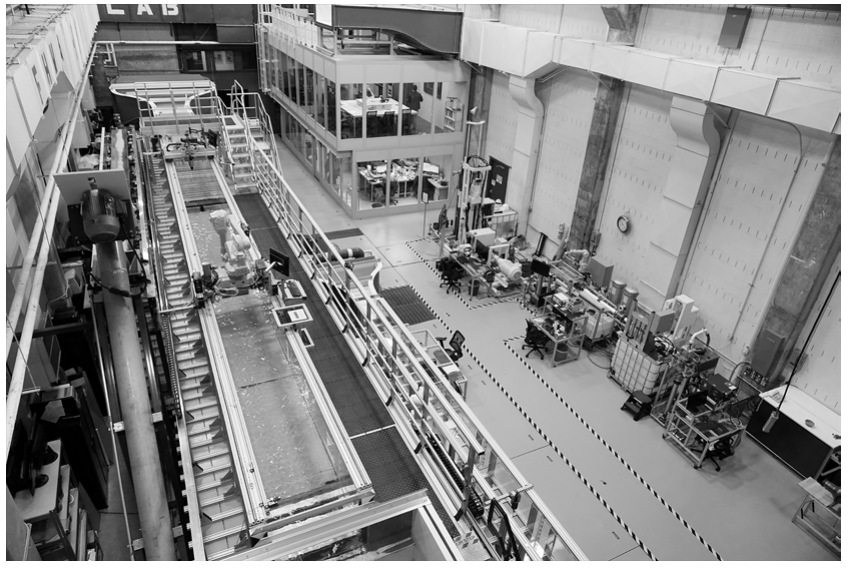

Figure 7. The FHWA's J. Sterling Jones Hydraulics Research Laboratory at the Turner-Fairbank Highway Research Center

simulating hydrographs. The flume carriage housed an automated three-axis positioning system to position sensors at any location.

A point laser distance sensor was instrumented on the flume carriage to survey the distance between the bathymetry and the sensor. Elevation measurements were taken after the water had been drained to eliminate the negative influence of water on the laser distance sensor. These data were automatically converted into the elevation of each point on the bed. The original bed elevation was set prior to the test run and maintained the same for all cases using the same pier model under the same flow condition. Therefore, the difference between the surveyed elevation and the original elevation represents the final bathymetric change used to develop the models for the CFD experiments.

\subsection{Physical experiment results}

Figure 8 provides a comparison of the measured scour hole at the Feather River and the corresponding physical experiment for the MF event. The two upper graphs are surveyed Feather River bathymetry determined by sonar, and the two bottom photographs are the experimental results. The shapes are generally consistent. In both the field measurements and the flume modelling, the depth of the scour hole is larger in the area around the leading edge of the pier and relatively small in the area around the tailing edge. The modelling appears effective at matching the field observations for the original pier configuration. Therefore, it is reasonable to assume that the physical modelling will provide reasonable results for retrofitted pier configurations.

The Solidworks software program was used to create the computer-aided design (Cad) models for CFD modelling by importing the surveyed bathymetry data and pier models. Figure 9 shows the Cad models for the scour associated with the original pier configuration and the MF.
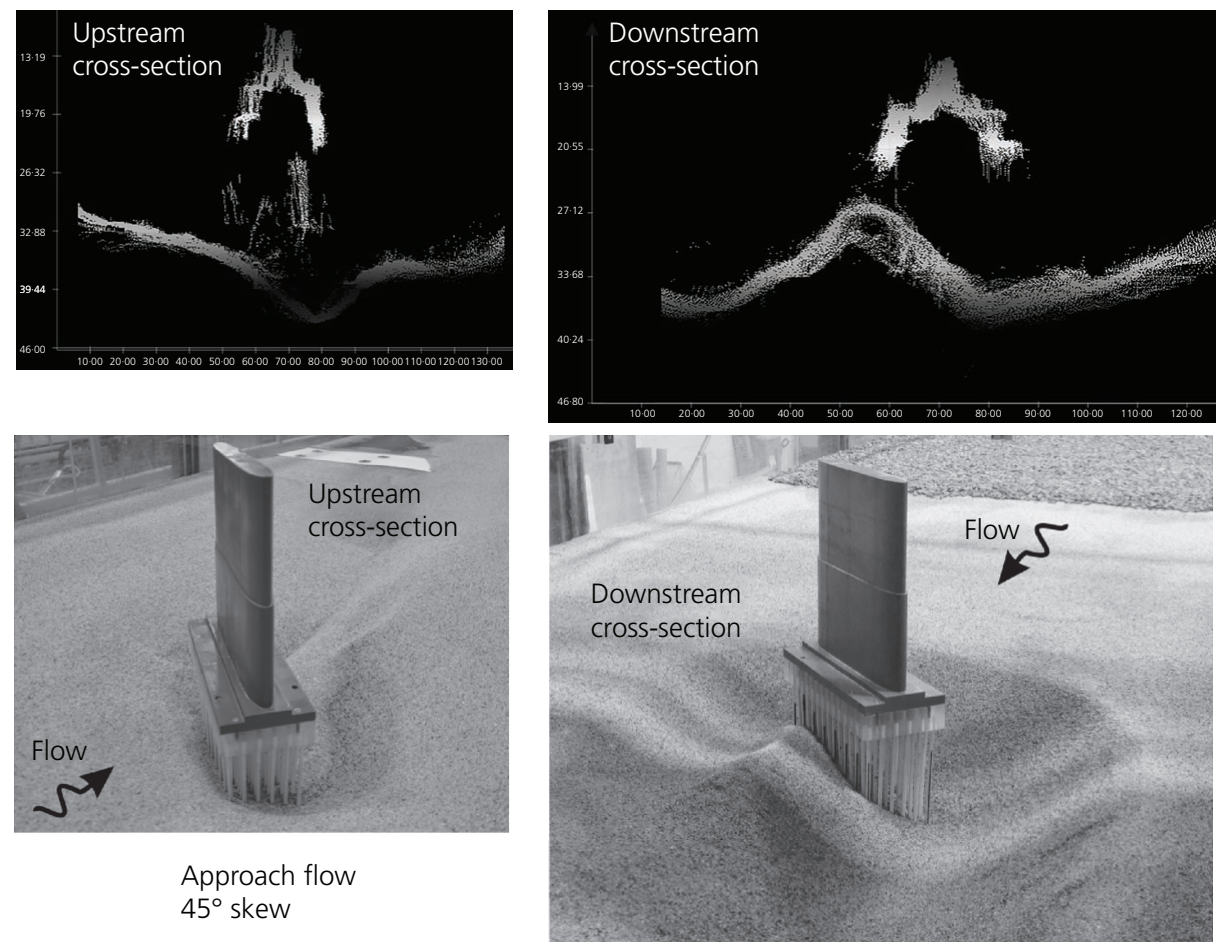

Figure 8. Comparison of measured and experimental scour hole shapes 
Forensic Engineering

Volume 172 Issue FE1
A hybrid approach to forensic study of

bridge scour

Kerenyi and Flora
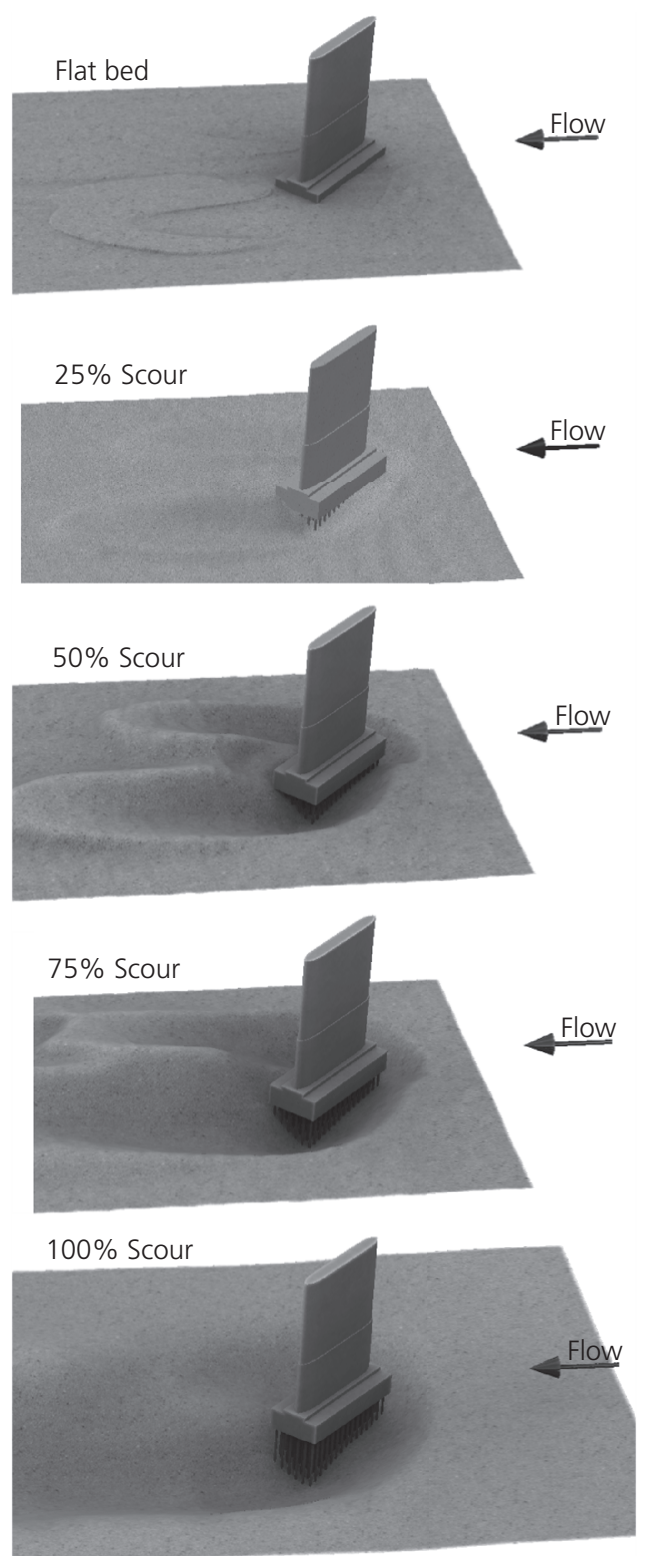

Figure 9. Cad models for the original pier configuration and the MF

\section{Development of the CFD models}

\subsection{Overview}

The development of the CFD models for this study is described in accordance with the general procedure for CFD using the Star$\mathrm{CCM}+$ software program. The pier models and scour bathymetry from the flume experiments were used to create the CFD models. Then, the CFD modelling formed the basis for quantifying shear stresses throughout the modelling surfaces.

\subsection{CFD geometry and physical continuum models}

Figure 10 shows an example of the CFD geometry for the 100year flow with $50 \%$ of the maximum scour at the original pier.

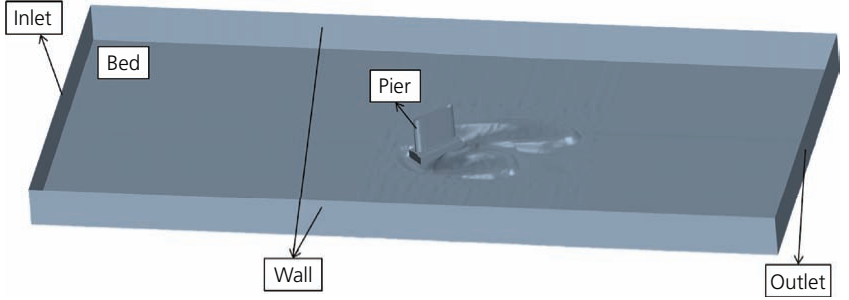

Figure 10. CFD geometry for the 100 -year flow with $50 \%$ of the maximum scour at the original pier

The pier from the Cad design and the bed from the scour bathymetry from the flume experiment are supplemented by two sides and an inlet and outlet. The flow direction is from the inlet to the outlet. Figure 11 displays an example of a computational mesh derived from the model geometry for the MF case at $50 \%$ scour for the original pier configuration. This mesh has sufficient details to represent the shapes of the leading and tailing edges of the pier and the H-piles. The density of the mesh cells varies depending on the detail required. The smallest mesh cells are used around the pier, while the largest mesh cells are used in the areas removed from the pier. Intermediate-sized mesh cells are applied in other parts of the Cad model. Using a range of mesh cell sizes allows a smooth transition between areas with different mesh cell densities. Even though this kind of mesh satisfies the requirements of the geometry, there are additional requirements for adequately representing the flow field. CFD physical continuum models were developed to simulate open-channel flows. Selecting the most appropriate turbulence, free surface and wall function models is critical to represent the flume experiments properly. For this study, the volume-of-fluid (VOF) model was activated to simulate the free surface. Since the focus of the CFD model is to obtain wall shear stress distributions around the pier and the water depth is large enough to eliminate the influence of the motion of the free surface on the bed, the most significant purpose of the VOF model is to ensure that the water flow in the geometry is an open-channel flow.

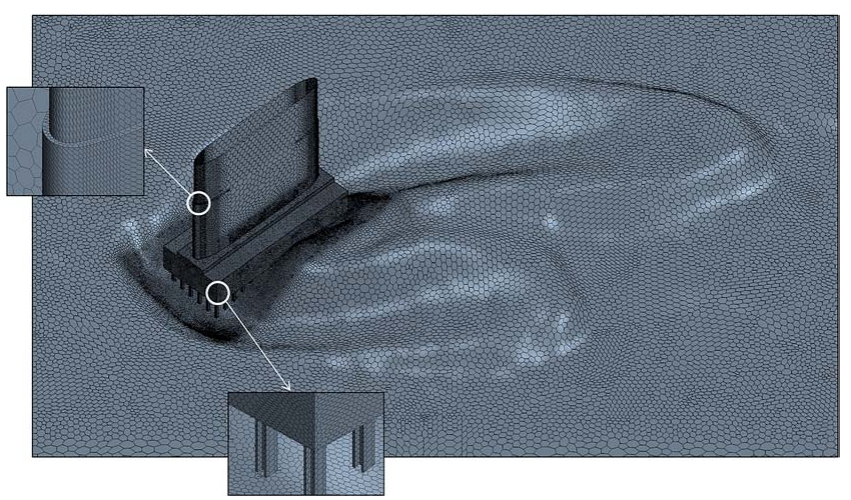

Figure 11. Mesh of the MF case at 50\% scour for the original pier configuration 
The realisable $K$-epsilon and Reynolds-averaged Navier-Stokes (Rans) models were activated to simulate turbulent flow for this study. The realisable $K$-epsilon model is a recently developed turbulence model that is recommended for use with Rans to simulate unsteady turbulent flow. This model was developed from the standard $K$-epsilon model. The main advantage is that a critical coefficient of this model is expressed as a function of the mean flow and turbulence properties rather than an assumed constant as in the standard $K$-epsilon model. Therefore, this model satisfies certain mathematical constraints on the normal stresses consistent with the physics of real turbulence.

The wall functions are a set of semi-empirical functions used to satisfy the physics of water flow in near-wall regions. They have a close relation with the distribution of wall shear stress. In the Star$\mathrm{CCM}+$ software program, there are three wall functions: $(a)$ high $y^{+}$ wall treatment for the coarse mesh, $(b)$ low $y^{+}$wall treatment for the fine mesh and $(c)$ all $y^{+}$wall treatment. The third wall function is a hybrid treatment that attempts to emulate both the first and second wall functions. The advantage of the third wall function is that the modeller does not have to identify which walls require the individual high and low functions. Moreover, the velocity vectors given by combining the two-layer model and any turbulence model are physically meaningful. The two-layer all $y^{+}$wall treatment was applied in this study to simulate water flow in near-wall regions. The mesh cell size also influences the wall shear stress distributions. Figures 12 and 13 display the wall shear stress distributions for the fine and very fine meshes, respectively. The distributions are similar. Therefore, the fine mesh appears appropriate for representing the wall shear distribution while being more economical.

\section{The wall shear stress decay function}

The simulated wall shear stress distributions of the physical experiments were analysed to determine a decay trend of wall shear stress with scour. An envelope decay function was also developed by combining the CFD data and the data from physical experiments reported by Annandale (2006). Simulation results from the CFD models of the flow around a rectangular pier were used to validate the decay functions. The wall shear stress values of selected points around the pier were taken to develop an

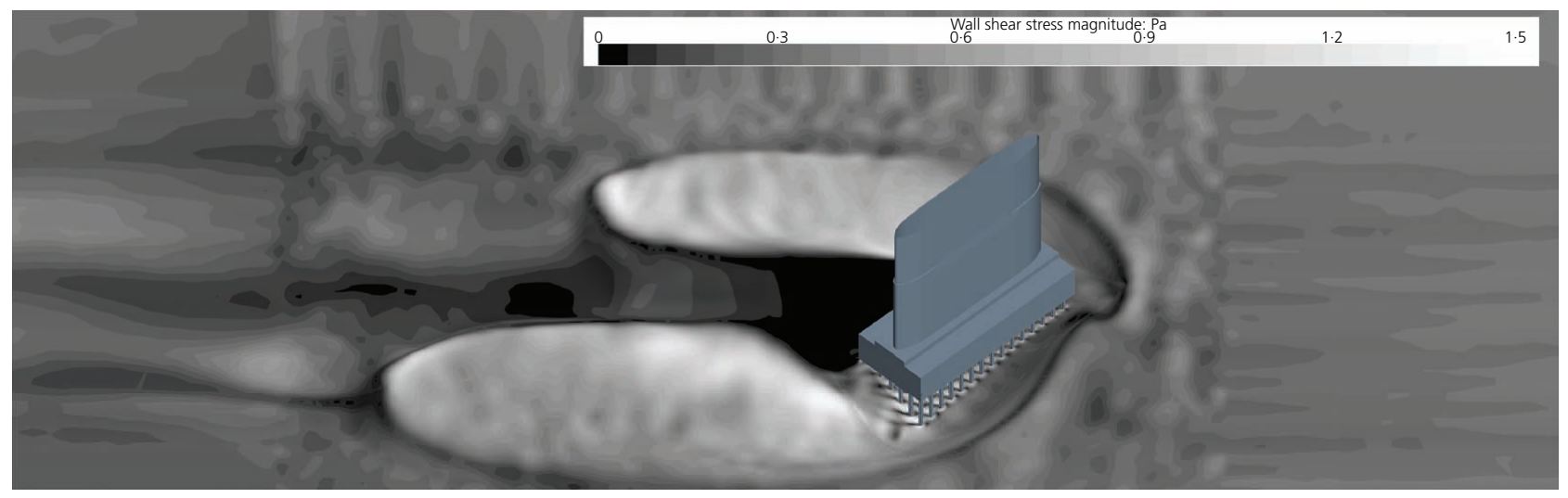

Figure 12. Wall shear stress distribution of the fine mesh

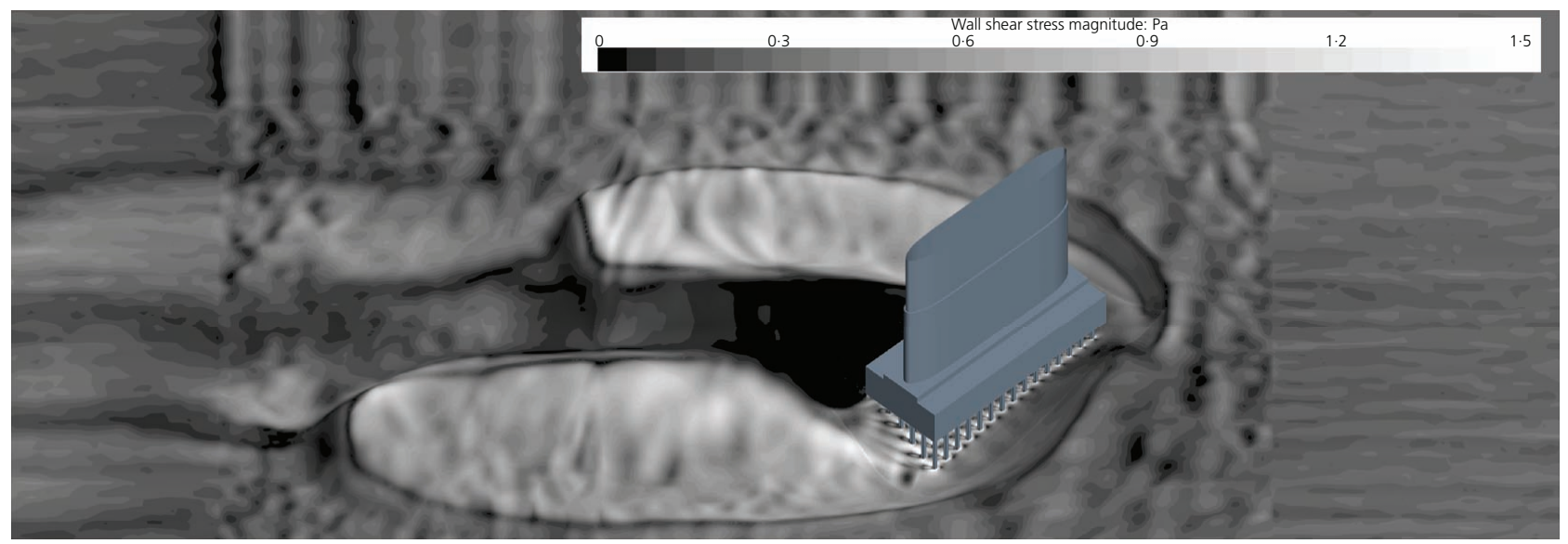

Figure 13. Wall shear stress distribution of the very fine mesh 
appropriate function to describe this trend. In addition, the wall shear stress distributions for the flat-bed cases under the same flow conditions were used to analyse the potential influence of scour on the retrofit design against the original design at the Feather River Bridge.

\subsection{Wall shear stress distributions}

Figure 14 displays the wall shear stress distributions for the MF event and original pier configuration for the flat bed, 50\% scour, and $100 \%$ scour conditions. For the flat bed case, the area with large shear stress is around the foundation of the pier. Therefore, scour first begins in this area. The bed material particles in this area are removed by the water flow and a small scour hole forms. In the $50 \%$ scour case, both the area and the depth of the scour hole become larger, while the area with large wall shear stresses and the shear stresses around the pier become smaller. The wall shear stress distribution for the $100 \%$ scour case shows that there is not an area with notably high wall shear stresses around the pier, suggesting that scour would stop with this bathymetry. These distributions reflect a clear decay trend of wall shear stress with scour depth.

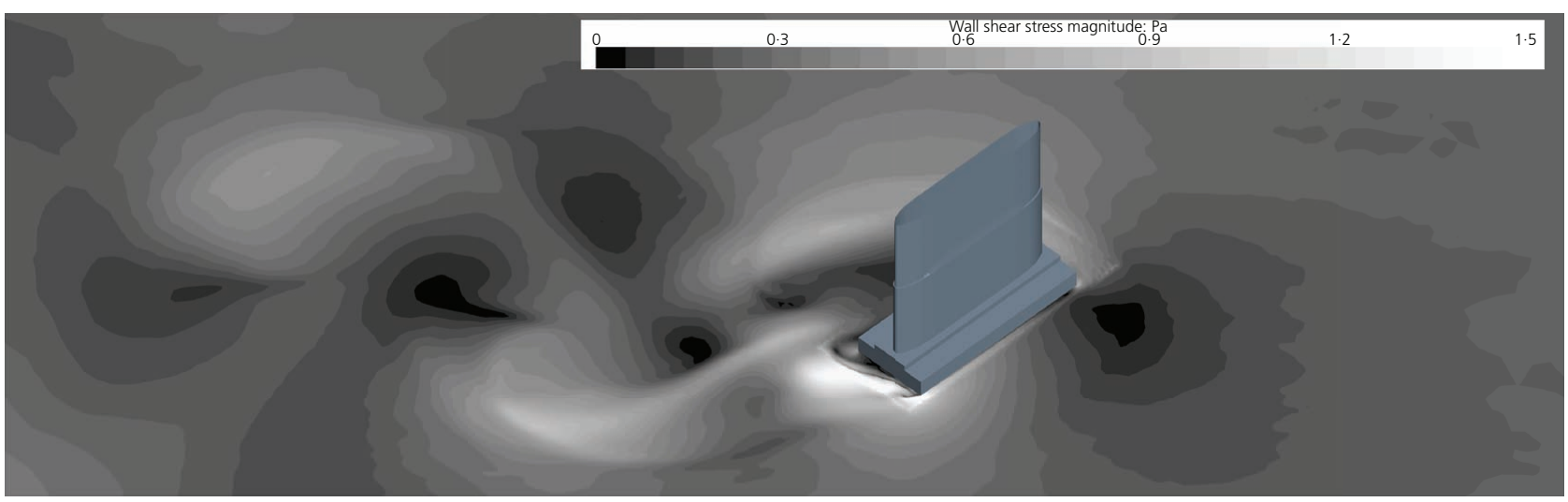

(a)

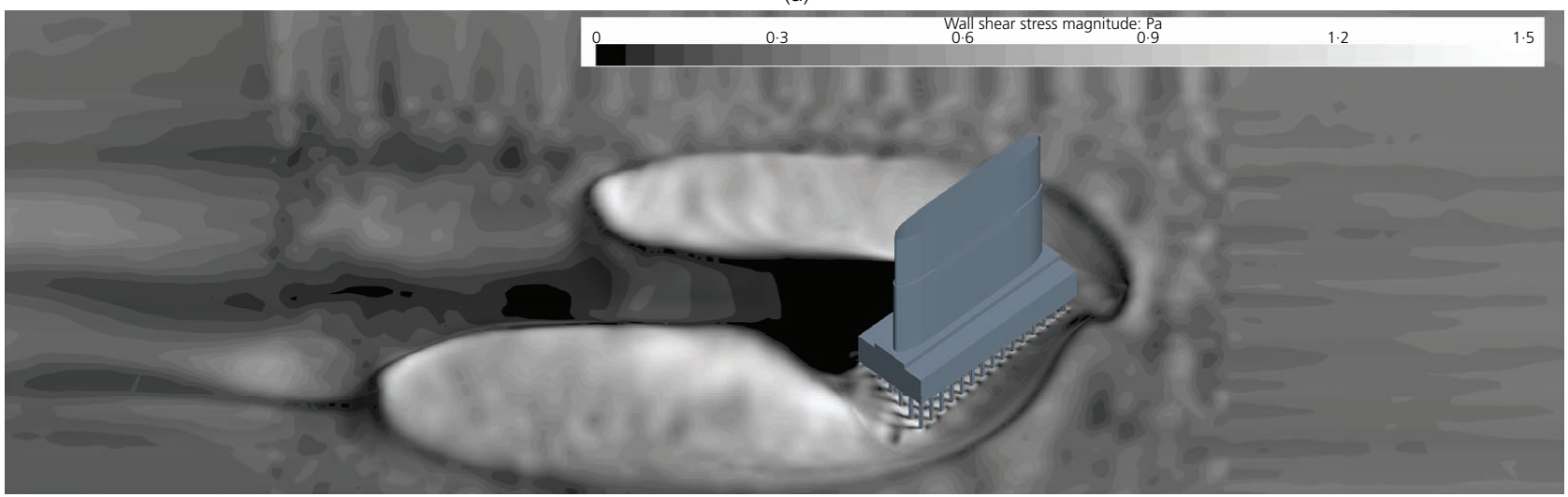

(b)

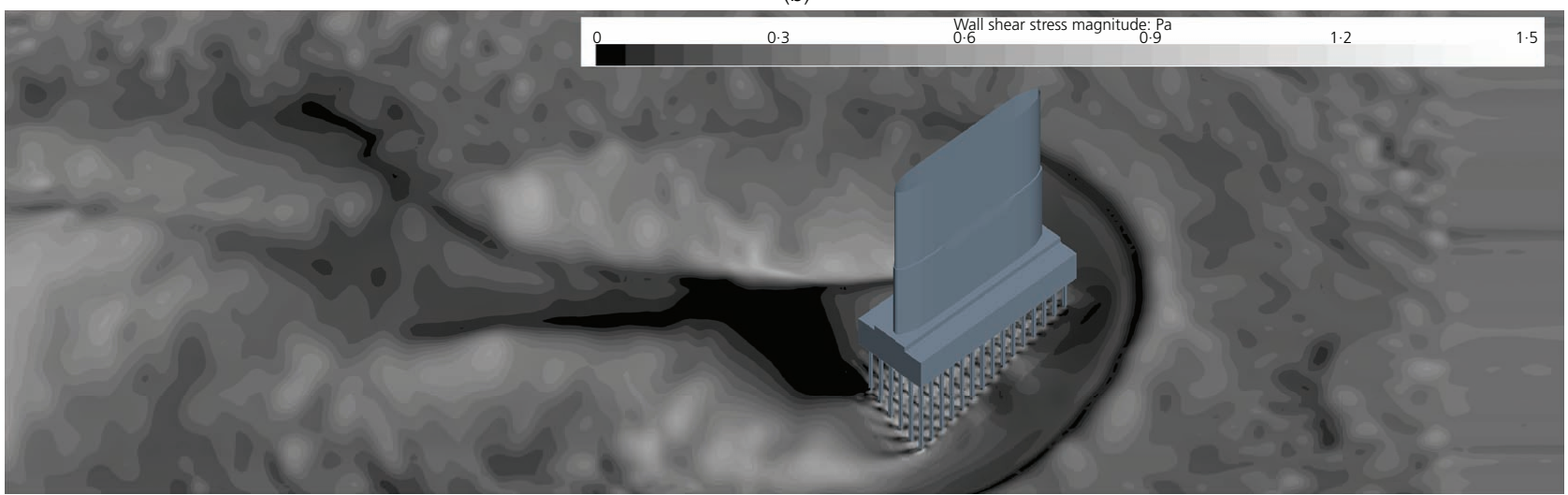

(c)

Figure 14. Wall shear stress distribution for the MF event and original pier configuration cases: (a) flat bed, (b) 50\% scour and (c) $100 \%$ scour conditions 
The CFD modelling estimates wall shear stresses throughout the bed surface. For analysis of the decay function, the wall shear stress value for the flat bed cases was taken at the location of maximum wall shear stress around the foundation. This is generally near where the scour depth will ultimately be the maximum.

A dimensionless shear stress quantity is defined by Equation 1 . The dimensionless shear stress is the ratio of the wall shear stress $\left(\tau_{\mathrm{w}}\right)$ at the point of scour to the approach bed shear stress $\left(\tau_{\mathrm{a}}\right)$. The approach bed shear stress is calculated by using Equation 2.

$$
\text { 1. } \tau_{*}=\frac{\tau_{\mathrm{w}}}{\tau_{\mathrm{a}}}
$$

where $\tau_{*}$ is the dimensionless shear stress.

2. $\tau_{\mathrm{a}}=\frac{(V n)^{2}}{R_{\mathrm{h}}^{1 / 3}} \rho \boldsymbol{g}$

where $V$ is the approach flow velocity; $n$ is Manning's roughness coefficient; and $R_{\mathrm{h}}$ is the hydraulic radius.

Figure 15 provides a graphical summary of these data. Within each group (MF_O: MF original pier; MF_R: MF retrofit design; Q100_O: 100-year flood original pier; Q100 R: 100-year flood retrofit design), the dimensionless shear stress drops as the relative scour depth increases. As the maximum scour depth is approached, the ability of the flow field to erode further diminishes until the maximum scour depth for the flow conditions, bed material and pier configuration is reached.

For the flat bed condition ( $0 \%$ relative scour depth), the wall shear stress is greater for the larger 100-year flow (Q100) than it is for the MF for both the original and retrofit pier configurations.

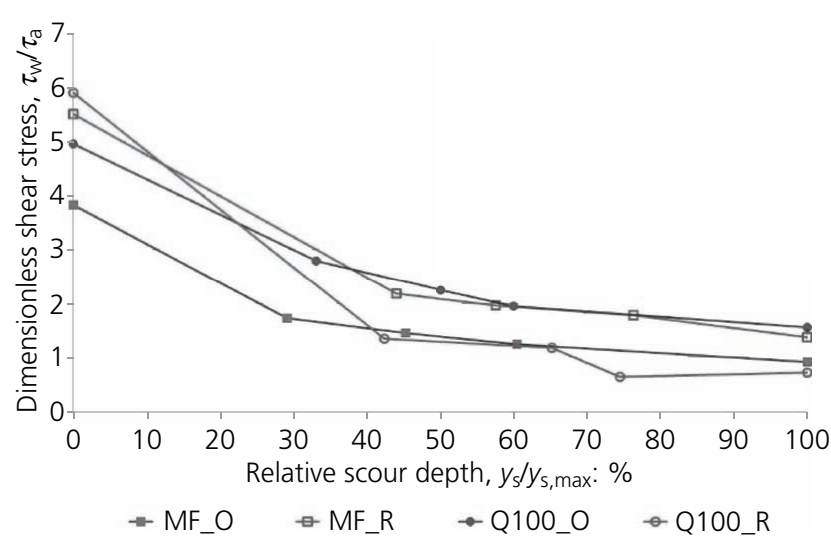

Figure 15. Dimensionless shear stress plotted against relative scour depth
In addition, the wall shear stress for the retrofit pier configuration is greater than it is for the original pier configuration for a given discharge condition. Comparison of Figure 16 (original pier design with MF) with Figure 17 (retrofit pier design with MF) clearly shows the increase in bed shear stress for the retrofit pier configuration compared with the original pier configuration. Therefore, while the retrofit design may provide additional support capacity for the pier, it may also increase the scour depth compared with the original pier design.

Theoretically, it is expected that the wall shear stress at the bottom of the scour hole at $100 \%$ of the maximum scour would approximate the critical shear stress of the bed material. It is also expected that the dimensionless shear stress for the $100 \%$ scour condition would approximate 1.0 if the approach shear stress is at the critical value for the bed material. This value ranges from 0.71 to 1.37 for the four groups.

\subsection{Decay function development}

A two-parameter exponential function was selected to fit the data plotted in Figure 15 considering two constraints. First, the dimensionless scour ratio should be equal to 1 when the relative scour depth is $100 \%$. Second, the value of the dimensionless shear stress will be set to the average dimensionless shear stress when the relative scour depth is zero (flat bed). For the four flat bed cases, the average dimensionless scour depth is $5 \cdot 05$. Equation 3 is the resulting equation based on the specified constraints

3. $\frac{\tau_{\mathrm{w}}}{\tau_{\mathrm{a}}}=5.05 \times \exp \left(-1.62 \times \frac{y_{\mathrm{s}}}{y_{\mathrm{s}, \max }}\right)$

where $y_{\mathrm{s}}$ is the pier-scour depth.

Figure 18 overlays the average decay function on the experimental data for comparison. With the exception of data points at 0 and

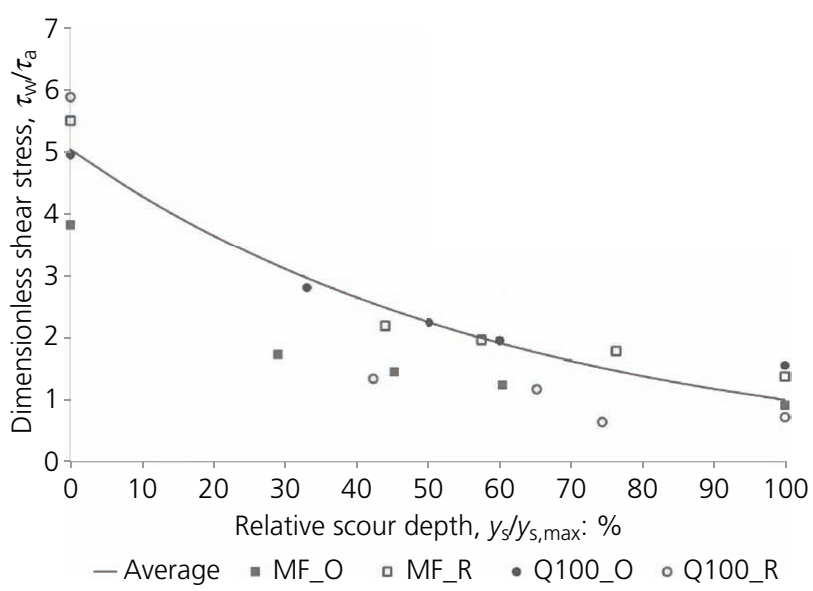

Figure 16. Wall shear stress distribution for the original pier design with MF 


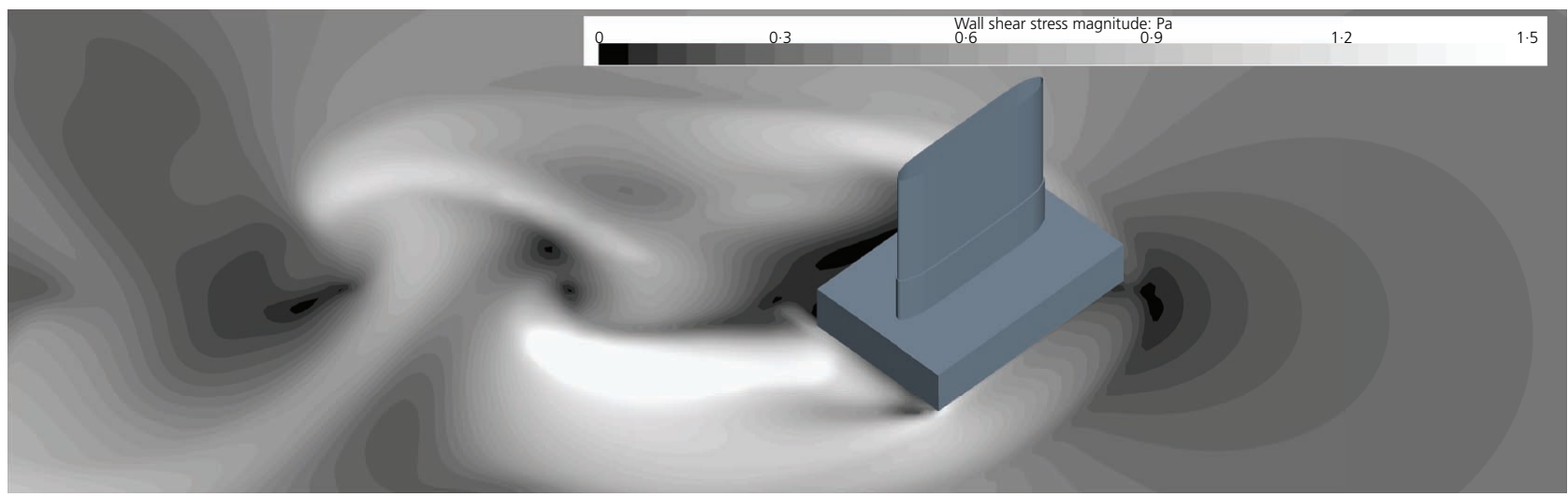

Figure 17. Wall shear stress distribution for the retrofit pier design with MF

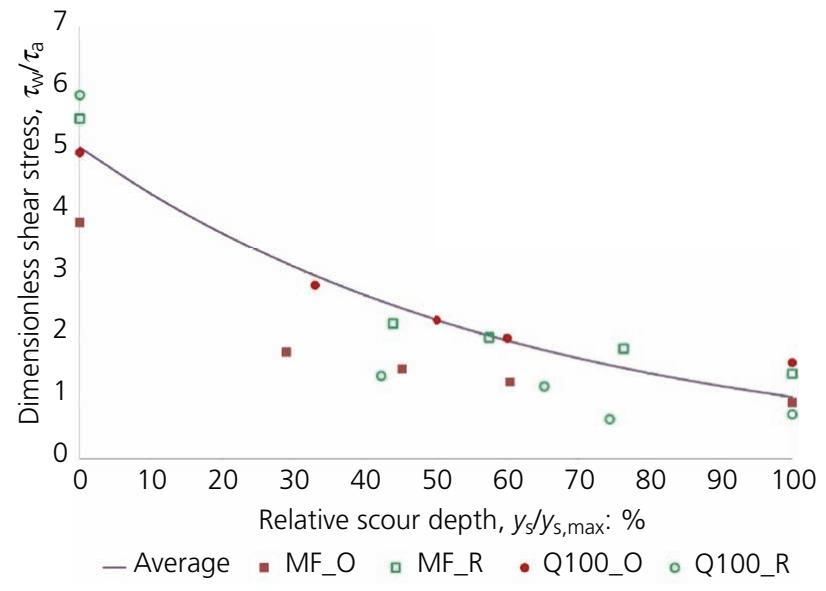

Figure 18. Decay function of wall shear stress

$100 \%$ scour, the average decay function generates estimates of dimensionless shear stress equal to or greater than the data points. The variation of data at zero relative scour is influenced by the pier configuration, and the variation at all points is influenced by how close the approach shear stress is to the critical shear.

\subsection{Validation of the decay function}

Annandale (2006) reported data from a series of physical experiments designed to study the relation between stream power and scour. These physical experiments included cases with different regular-shaped piers under different flow conditions with non-cohesive clean sand for the bed material. The data reported by Annandale (2006) include the wall shear stress, approach velocity, Darcy friction factor, flow depth and scour depth.

The potential maximum scour depth of each case was calculated using the HEC-18 pier-scour equation (Arneson et al., 2012). The relative scour depth was estimated as the ratio of the measured scour depth to the potential maximum scour depth. The dimensionless shear stress was also estimated from the data set.
The results are plotted with the data from this study in Figure 19. The Annandale data also clearly reflect a decay trend of dimensionless wall shear stress with relative scour depth. However, most of the Annandale data plot above the average decay function curve.

The three rectangular pier data points discussed earlier are also plotted in Figure 19. The data points at relative scour depths of 45 and $100 \%$ plot nearly directly on the average decay function, while the data point at $0 \%$ scour plots above the function.

A second 'envelope' curve is also shown in Figure 19. This curve was developed by multiplying Equation 3 by 2 so that approximately $95 \%$ of the data points are below this envelope curve. The resulting function is shown in the following equation

$$
\text { 4. } \frac{\tau_{\mathrm{w}}}{\tau_{\mathrm{a}}}=10 \cdot 1 \times \exp \left(-1.62 \times \frac{y_{\mathrm{s}}}{y_{\mathrm{s}, \max }}\right)
$$

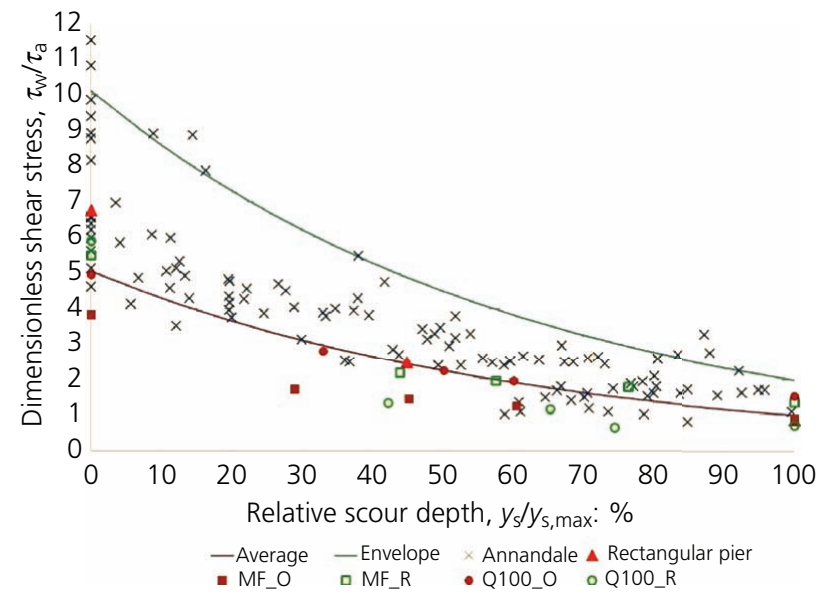

Figure 19. Graph of shear stress amplification plotted against relative depth 


\section{Application of the decay function to the Feather River Bridge}

Pier-scour-estimation methods and laboratory pier-scour experiments generally assume homogeneous soil conditions. However, many bridge piers are located in heterogeneous conditions with multiple soil layers with varied scour resistance properties. A decay function of wall shear stress with scour depth allows a layer-by-layer evaluation of scour potential by matching the shear stress imposed by the flow at a given scour depth with the resistance of the soil at that depth. This can be useful in the design of new bridge piers by potentially identifying a buried soil layer that has the capacity to prevent further scour. It may also be useful in evaluating existing bridge scour situations, such as pier 22 of the Feather River Bridge, to assess the likelihood of further scour.

Data for the soil layering and characteristics in the vicinity of pier 22 were taken from the Feather River Emergency Scour Study (Flora, 2011). These data include the elevation and median grain size of the layers as summarised in Table 1. As a reference point, the top of the pier 22 foundation (pile cap) is at an elevation of $35 \mathrm{ft}(10.7 \mathrm{~m})$. The scour hole created by the MF event reached an elevation of $6 \mathrm{ft}(1.83 \mathrm{~m})$ upstream of the pier.

As seen in Table 1, the resistance of each soil layer (critical shear stress) varies significantly. Figure 20 displays the critical shear with respect to elevation. Theoretically, scour will stop when the resisting ability of the soil material exceeds the shear stress generated by the flowing water.

A hypothesis for this study is that the decay functions (average and envelope) described by Equations 3 and 4 can be used to estimate the applied shear stress at the surface before scour begins and at the bottom of the scour hole as it is progressing. For the average decay function, the shear stress at the surface before scour begins is approximately five times the approach shear stress and the shear stress at the bottom of the scour hole at $100 \%$ scour depth is one times the approach shear stress. Similarly, for the envelope decay function, the shear stress at the surface is approximately ten times

Table 1. Soil characteristics at pier 22

\begin{tabular}{|cccc|} 
Elevation: ft & $\begin{array}{c}\text { Depth below top of } \\
\text { foundation: } \mathbf{f t}\end{array}$ & $\begin{array}{c}\boldsymbol{D}_{\mathbf{5 0}}: \\
\text { in. }\end{array}$ & $\begin{array}{c}\text { Critical shear } \\
\text { stress: lbf/ft }\end{array}$ \\
\hline 25.0 & 10.0 & - & - \\
12.9 & 22.1 & 0.08 & 0.032 \\
-0.7 & 35.7 & 0.08 & 0.032 \\
-2.7 & 37.7 & 0.47 & 0.235 \\
-6.0 & 41.0 & 0.47 & 0.235 \\
-11.0 & 46.0 & 0.01 & 0.004 \\
-15.7 & 50.7 & 0.01 & 0.003 \\
-18.7 & 53.7 & 3.94 & 1.938 \\
-21.5 & 56.5 & 5.91 & 2.906 \\
-21.7 & 56.7 & 5.91 & 2.906 \\
-41.0 & 76.0 & 7.01 & 3.448 \\
-45.7 & 80.7 & - & - \\
\hline
\end{tabular}

$1 \mathrm{ft}=0.305 \mathrm{~m} ; 1 \mathrm{in} .=1 \mathrm{inch}=25.4 \mathrm{~mm} ; 1 \mathrm{lbf} / \mathrm{ft}^{2}=1$ pound-force $/ \mathrm{ft}^{2}=$ 47.9 $\mathrm{Pa}$

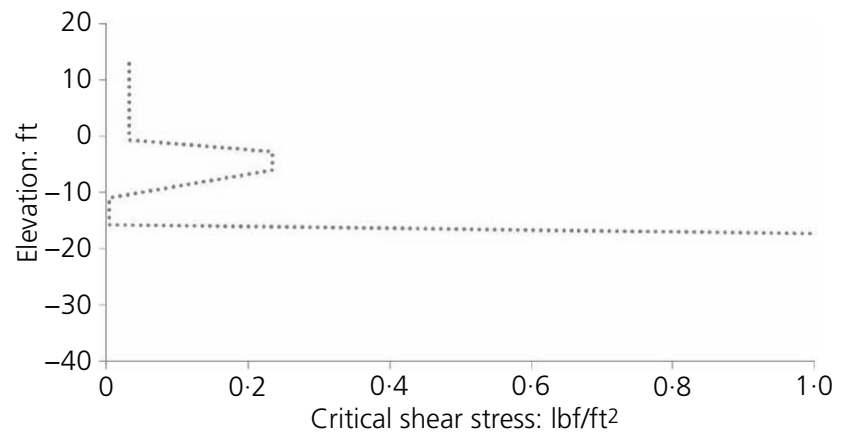

Figure 20. Critical stress by elevation at pier 22. $1 \mathrm{ft}=0.305 \mathrm{~m}$; $1 \mathrm{lbf} / \mathrm{ft}^{2}=47.9 \mathrm{~Pa}$

the approach shear stress and the shear stress at the bottom of the scour hole at $100 \%$ scour depth is two times the approach shear stress. In both cases, it is assumed that the approach shear stress is approximately equal to the critical shear stress.

For this example, application to Feather River Bridge pier 22, the complex pier foundation method for estimating scour described in HEC-18 is used to compute the maximum scour (Arneson et al., 2012). For the MF conditions using the original pier configuration, a scour depth $\left(y_{\mathrm{s}}\right)$ of $29.4 \mathrm{ft}(9 \mathrm{~m})$ was estimated in the emergency scour study. Considered relative to a bed surface at an elevation of $25 \mathrm{ft}(7 \cdot 6 \mathrm{~m})$, the scour hole bottom would be at an elevation of $-4.4 \mathrm{ft}(1 \cdot 3 \mathrm{~m})$. A similar procedure could be applied with the 100 year condition for the original pier. Although this condition was not assessed in the emergency study, a scour depth of $35.3 \mathrm{ft}(10.7 \mathrm{~m})$ (an increase of $20 \%$ ) to an elevation of $-10 \cdot 3 \mathrm{ft}(3 \cdot 1 \mathrm{~m})$ was assumed to illustrate the method.

Tables 2 and 3 summarise the computed shear stresses for both the MF and the 100-year flood (Q100) using the average (Avg.) and envelope (Env.) decay functions. These values are also plotted in Figure 21. When the applied shear stress is larger than the critical shear stress, continued scour is expected.

For both the MF and the 100-year events, the analysis suggests that the scour would stop at an elevation of $-2 \cdot 7 \mathrm{ft}(0.8 \mathrm{~m})$ when the bed layer with $D_{50}$ equal to 0.47 inches $(12 \mathrm{~mm})$ is reached.

Table 2. Shear stresses for the original pier 22 configuration for MF

\begin{tabular}{cccc|} 
Elevation: ft & $\begin{array}{c}\text { Relative } \\
\text { scour } \\
\text { depth MF }\end{array}$ & $\begin{array}{c}\text { Shear stress for } \\
\text { MF and Avg } \\
\text { curve: lbf/ft }\end{array}$ & $\begin{array}{c}\text { Shear stress for } \\
\text { MF and Env } \\
\text { curve: Ibf/ft }\end{array}$ \\
\hline 25.0 & 0.00 & 0.225 & 0.450 \\
12.9 & 0.41 & 0.116 & 0.231 \\
-0.7 & 0.87 & 0.055 & 0.109 \\
-2.7 & 0.94 & 0.049 & 0.098 \\
-6.0 & 1.05 & - & - \\
-11.0 & 1.22 & - & - \\
\hline
\end{tabular}

$1 \mathrm{ft}=0.305 \mathrm{~m} ; 1 \mathrm{lbf} / \mathrm{ft}^{2}=47.9 \mathrm{~Pa}$ 
Table 3. Shear stresses for the original pier 22 configuration for Q100

\begin{tabular}{cccc} 
Elevation: $\mathbf{f t}$ & $\begin{array}{c}\text { Relative } \\
\text { scour } \\
\text { depth } \\
\text { Q100 }\end{array}$ & $\begin{array}{c}\text { Shear stress for } \\
\text { Q100 and Avg } \\
\text { curve: Ibf/ft }\end{array}$ & $\begin{array}{c}\text { Shear stress for } \\
\text { Q100 and Env } \\
\text { curve: lbf/ } / \mathrm{ft}^{2}\end{array}$ \\
\hline 25.0 & 0.00 & 0.407 & 0.814 \\
12.9 & 0.34 & 0.234 & 0.467 \\
-0.7 & 0.73 & 0.125 & 0.250 \\
-2.7 & 0.78 & 0.114 & 0.228 \\
-6.0 & 0.88 & 0.098 & 0.196 \\
-11.0 & 1.02 & 0.078 & 0.156 \\
\hline
\end{tabular}

$1 \mathrm{ft}=0.305 \mathrm{~m} ; 1 \mathrm{lbf} / \mathrm{ft}^{2}=47 \cdot 9 \mathrm{~Pa}$

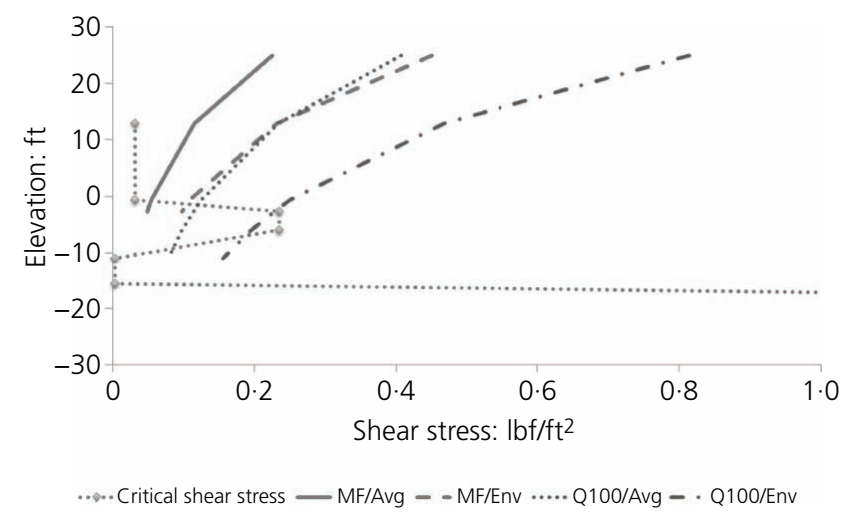

Figure 21. Shear stress comparison at for the original pier 22 configuration. $1 \mathrm{ft}=0.305 \mathrm{~m} ; 1 \mathrm{lbf} / \mathrm{ft}^{2}=47.9 \mathrm{~Pa}$

This is also true when using the envelope curve, although, for the 100 -year flood, the estimated shear at an elevation of $-2.7 \mathrm{ft}$ $(0 \cdot 8 \mathrm{~m})\left(0 \cdot 28 \mathrm{lbf} / \mathrm{ft}^{2}\right)(13 \cdot 4 \mathrm{~Pa})$ is only slightly less than the critical shear $\left(0 \cdot 35 \mathrm{lbf} / \mathrm{ft}^{2}\right)(16 \cdot 7 \mathrm{~Pa})$.

One practical question that arises from this analysis is whether the soil layer located at an elevation of $-2.7 \mathrm{ft}(0.8 \mathrm{~m})$ is sufficiently thick to arrest the scour development truly? Or given the variability and uncertainty of subsurface conditions, could the scour break through this relatively thin soil layer?

After the MF, it was observed that that the scour hole stopped at an elevation of $6 \mathrm{ft}(1.8 \mathrm{~m})$. This raises the question of why the scour during the MF did not continue for another $8.7 \mathrm{ft}(2.6 \mathrm{~m})$ to the predicted elevation of $-2.7 \mathrm{ft}(0.8 \mathrm{~m})$. Additional applications of this method would be required to address this question, but explanations may include the following.

- Previous scour events might have armoured the hole with larger sediments, not allowing further scouring.

- The flood event was too short for the scour hole to reach its maximum depth.

- The critical shear stress of the soils was underestimated.

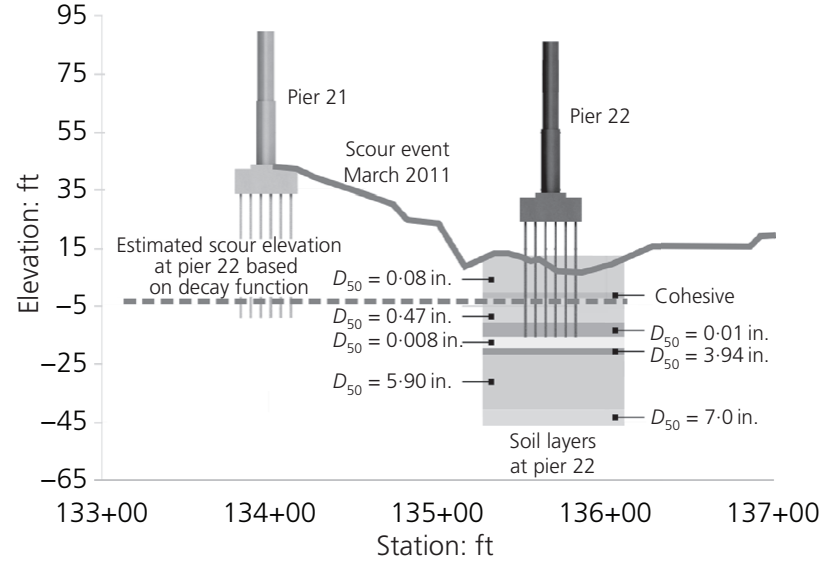

Figure 22. Comparison of observed scour against predicted scour for the MF and visualisation of the soil characteristics at pier 22. $1 \mathrm{ft}=0.305 \mathrm{~m} ; 1$ in. $=2.54 \mathrm{~mm}$

- The HEC-18 complex pier-scour methodology overestimated the maximum scour.

- The approach shear was greater than critical shear (live bed), thereby overestimating the estimates of shear at each scour depth.

- The average decay function does not take into account the pier/foundation geometry by assuming that the applied shear at the surface before scour is initiated is five times the approach shear regardless of the geometry.

The last explanation could be used to explain under- or overestimates of scour depending on the pier/foundation geometry. Figure 22 summarises the observed scour during the MF and the predicted scour depth using the decay function approach. The figure also visualises the soil characteristics at pier 22 listed in Table 1.

\section{Summary and recommendations}

Pier scour, and bridge scour generally, continues to be a major concern for protecting the travelling public and investment in transportation infrastructure. This study investigated pier scour at complex pier configurations with multilayer soil systems. A shear stress decay function was developed and applied to the Feather River Bridge in California.

Annandale (2006), based on a set of physical experiments, observed a decay trend of stream power with increases in scour depth. However, physical experiments are limited in their utility to measure shear stress directly. At the same time, CFD simulation is limited in its capability to characterise the scour process accurately. For this study, a hybrid approach of physical experiments and CFD simulations was developed to study the relation between wall shear stress and scour depth

\subsection{Summary}

The activities for this research may be categorised into two areas: (a) application of a hybrid physical and CFD modelling protocol 
to develop shear stress and scour depth data and $(b)$ development of a decay function of wall shear stress.

\subsubsection{Hybrid physical and CFD modelling}

With the surveyed bathymetries of the physical experiments, a series of CFD models was developed. After running the models to a quasi-steady state, the unsteady CFD models developed in the Star-CCM + software program effectively represented the steady state. Scour data from the physical experiments combined with the shear stresses from the CFD simulations demonstrated a decay trend of wall shear stress with increasing scour.

\subsubsection{Decay function development}

The bathymetry in the physical experiments was formed using non-cohesive clean sand. To eliminate the potential influence of form drag caused by the shape change of the bathymetry, the value of wall shear stress from the CFD experiments was taken at the point with the largest scour depth for each case. These shear stresses were combined with relative scour depths to develop a decay function. Previous physical experimental data were used to verify and calibrate the decay function.

Two decay functions were developed: an average decay function that represents the data from this study and an envelope decay function that conservatively encompasses the broader data set. The envelope function was derived by multiplying the average function by a factor of 2 . The result was that this function enveloped $95 \%$ of the experimental data.

\subsubsection{Decay functions for the Feather River Bridge}

The averaged and enveloped decay functions were applied for the MF to explain why scour ceased at $30 \mathrm{ft}(9 \cdot 1 \mathrm{~m})$ (elevation $6 \mathrm{ft}$
$(1 \cdot 8 \mathrm{~m}))$. The decay function approach estimated a deeper scour depth at elevation $-2.7 \mathrm{ft}(0.8 \mathrm{~m})$. Several reasons for the discrepancy are explained in this paper.

\subsection{Recommendations}

This study successfully developed a hybrid approach for modelling complex pier scour to develop data of shear stress against scour depth. Recommendations for further work to extend this work include

- further development of CFD technology to provide mobile bed capabilities to model scour and to explore how instantaneous shear may contribute by using large-eddy simulation or detached-eddy simulation turbulence models

- additional investigation of the scour behaviour of riverbed materials with multiple layers with varying scour resistance properties to expand real-world application of scour technology.

\section{REFERENCES}

Annandale G (2006) Scour Technology: Mechanics and Engineering Practice. McGraw-Hill, New York, NY, USA.

Arneson L, Zevenbergen L, Lagasse P and Clopper P (2012) Evaluating Scour at Bridges, 5 th edn. Federal Highway Administration, Washington, DC, USA, HEC-18, FHWA-HIF-12-003.

Flora K (2010) Advanced Hydraulic, Scour and Geomorphic Study Report. California Department of Transportation, Sacramento, CA, USA.

Flora K (2011) Feather River Emergency Scour Study. California Department of Transportation, Sacramento, CA, USA.

Lee G, Liang Z, Shen J and O'Connor J (2011) Extreme Load Combinations: a Survey of State Bridge Engineers. Multidisciplinary Center for Earthquake Engineering, University at Buffalo, Buffalo, NY, USA, MCEER-11-0007.

\section{How can you contribute?}

To discuss this paper, please email up to 500 words to the editor at journals@ice.org.uk. Your contribution will be forwarded to the author(s) for a reply and, if considered appropriate by the editorial board, it will be published as discussion in a future issue of the journal.

Proceedings journals rely entirely on contributions from the civil engineering profession (and allied disciplines). Information about how to submit your paper online is available at www.icevirtuallibrary.com/page/authors, where you will also find detailed author guidelines. 